ISSN: 2355-892x (Print)

Online: http://e-journal.sari-mutiara.ac.id/index.php/KesehatanMasyarakat

DOI: https://doi.org/10.51544/jkmlh.v6i2.2365

\title{
ANALISIS PERILAKU MASYARAKAT PASAR MENGENAI PENGGUNAAN RODENTISIDA DAN DAMPAKNYA TERHADAP KUCING LIAR
}

\author{
Nurul Fadhilatunnisa ${ }^{1}$, Sudarti ${ }^{2}$, Wachju Subchan ${ }^{3}$ \\ ${ }^{1}$ Program Studi Magister Pendidikan IPA Universitas Jember \\ ${ }^{2,3}$ Pendidikan Lingkungan Hidup Pascasarjana \\ Pendidikan IPA Universitas Jember \\ Jalan Kalimantan No. 37 Sumbersari Jember \\ Email: ${ }^{\text {a) }}$ urulfadhilatunnisa22@gmail.com \\ b) sudarti.fkip@unej.ac.id
}

\begin{abstract}
ABSTRAK
Penggunaan rodentisida yang kurang tepat oleh sebagian besar masyarakat pasar mengakibatkan berkurangnya populasi kucing liar (Felis catus) yang terdapat di pasar. Apabila hal tersebut terus dilakukan, maka dapat mengakibatkan punahnya spesies kucing liar di area tersebut. Penelitian ini bertujuan untuk mendeskripsikan tingkat pengetahuan dan sikap masyarakat pasar mengenai penggunaan rodentisida dan dampaknya terhadap kucing liar (Felis catus). Penelitian ini menggunakan metode survei yakni interview dan observasi terhadap 28 responden yang mengaku pernah menggunakan rodentisida. Hasil penelitian menunjukkan 35,7 \% responden memiliki tingkat pengetahuan rendah, 39,3\% memiliki tingkat pengetahuan sedang, dan $25 \%$ memiliki tingkat pengetahuan tinggi. Sedangkan untuk aspek sikap, mayoritas masyarakat memperoleh kriteria cukup baik dengan rata-rata 68.
\end{abstract}

Kata Kunci: Kucing Liar, Masyarakat Pasar, Pengetahuan dan Sikap, Rodentisida

ABSTRACT

Inappropriate use of rodenticides by most market communities has resulted in a reduction in the population of feral cats (Felis catus) found in the market. If this continues, it can lead to the extinction of feral cat species in the area. This study aims to describe the level of knowledge and attitudes of the market community regarding the use of rodenticides and their impact on feral cats (Felis catus). This study used a survey method, namely interviews and observations of 28 respondents who claimed to have used rodenticides. The results showed that $35.7 \%$ of respondents had a low level of knowledge, $39.3 \%$ had a moderate level of knowledge, and $25 \%$ had a high level of knowledge. As for the attitude aspect, the majority of the community obtained quite good criteria with an average of 68.

Keywords: Feral Cats, Market Society, Knowledge and Attitudes, Rodenticides.

\section{PENDAHULUAN}

Pestisida merupakan zat beracun yang sering digunakan untuk membasmi hama yang mengganggu kegiatan manusia. Pestisida merupakan zat kimia beracun atau campuran zat atau agen biologis yang dengan sengaja dimasukkan ke dalam lingkungan untuk mencagah, menghalangi, mengandalikan, dan/atau membunuh serta memusnahkan populasi serangga, gulma, 
ISSN: 2528-4002 (Media Online)

ISSN: 2355-892x (Print)

Online: http://e-journal.sari-mutiara.ac.id/index.php/KesehatanMasyarakat

DOI: https://doi.org/10.51544/jkmlh.v6i2.2365

hewan pengerat, jamur atau yang lainnya (Mahmood et. al., 2016).

Penggunaan pestisida merupakan salah satu bentuk kegiatan mitigasi dari serangan hama yang dapat dilakukan oleh manusia. Selain dalam sektor pertanian, beberapa jenis pestisida juga sering digunakan dalam sektor perekonomian area pasar yang bertujuan untuk menjadikan lingkungan pasar bebas hama sehingga barang-barang dagangan pasar tidak cepat rusak. Salah satu jenis pestisida yang sering digunakan di area pasar adalah rodentisida. Hal ini didukung dengan hasil observasi awal yang menunjukkan bahwa hampir seluruh pemilik kios di Pasar Ngrandu pernah menggunakan rodentisida untuk membasmi tikus.

Penggunaan rodentisida seringkali salah sasaran sehingga berdampak juga pada lingkungan dan biodiversitas yang terdapat di Pasar, salah satunya adalah kucing liar. Berdasarkan hasil wawancara dengan Ketua Paguyuban Pasar Ngrandu, sebelum ini sering kali terlihat kucing liar yang memakan bangkai tikus yang mati keracunan rodentisida. Hal tersebut dikarenakan bangkai tikus yang teracun dibuang di tempat sampah Pasar Ngrandu dan tercampur dengan sampah-sampah ikan maupun sampah organik lainnya, sehingga kucing-kucing liar sering mendatangi tempat

\section{METODE PENELITIAN}

Penelitian ini merupakan jenis penelitian deskriptif yang mendeskripsikan tingkat pengetahuan masyarakat Pasar mengenai dampak penggunaan rodentisida dan kaitannya dengan kucing liar (Felis catus). Sampel pada penelitian ini ditentukan dengan metode purposive sampling yang terdiri atas 28 responden yang mengaku pernah menggunakan rodentisida. Metode peneitian yang digunakan pada penelitian ini

adalah melakukan observasi awal, identifikasi masalah, dan, analisis hasil penyebaran kuisioner kepada 30 responden yang mengaku pernah menggunakan rodentisida. Penyebaran kuesioner bertujuan untuk menilai pengetahuan dan perilaku masyarakat terhadap penggunaan rodentisida di Pasar Ngrandu dan dampaknya terhadap biodiversitas kucing liar (Felis catus). 
ISSN: 2528-4002 (Media Online)

ISSN: 2355-892x (Print)

Online: http://e-journal.sari-mutiara.ac.id/index.php/KesehatanMasyarakat

DOI: https://doi.org/10.51544/jkmlh.v6i2.2365

Penskoran aspek pengetahuan dilakukan berdasarkan tabel berikut.

TABEL 1 Tabel Penilaian Aspek Pengetahuan

\begin{tabular}{lc}
\hline Kategori & Skor \\
\hline Benar & 1 \\
\hline Salah & 0 \\
\hline Tidak Yakin & 0 \\
\hline
\end{tabular}

Rata-rata nilai setiap indikator aspek pengetahuan dihitung dengan menggunakan rumus:

Dengan:

$$
\bar{x}=\frac{\sum x}{n}
$$

$\bar{x}=$ nilai rata-rata setiap indikator

$\sum x=$ jumlah data

$n=$ banyaknya data

Penskoran aspek sikap dilakukan berdasarkan tabel berikut.

TABEL 2 Tabel Penilaian Aspek Sikap

\begin{tabular}{lc}
\hline Kategori & Skor \\
\hline Sangat Setuju & 4 \\
\hline Setuju & 3 \\
\hline Tidak Setuju & 2 \\
\hline Sangat Tidak Setuju & 1 \\
\hline
\end{tabular}

Rata-rata nilai setiap indikator aspek sikap dihitung dengan menggunakan rumus:

Dengan:

$$
\bar{x}=\frac{\sum x}{n}
$$

$\bar{x}=$ nilai rata-rata setiap indikator

$\sum x=$ jumlah data

$n=$ banyaknya data

\section{HASIL DAN PEMBAHASAN}

Penyebaran lembar kuisioner telah dilakukan pada Bulan November 2021. Lembar kuisioner diisi oleh 28 responden yang merupakan masyarakat yang menggunakan rodentisida di Pasar Ngrandu.
Pengguna rodentisida di Pasar Ngrandu mayoritas merupakan pemilik toko bahan makanan. Hasil pengisian kuisioner oleh 28 responden tersebut disajikan sebagai berikut.

\section{Aspek Pengetahuan}

Hasil pengisian kuisioner aspek pengetahuan mengenai rodentisida dan dampak penggunaan rodentisida terhadap kucing liar dapat dilihat pada TABEL 3 berikut ini. 
Jurnal Kesehatan Masyarakat Dan Lingkungan Hidup

Vol. 6 No. 22021

ISSN: 2528-4002 (Media Online)

ISSN: 2355-892x (Print)

Online: http://e-journal.sari-mutiara.ac.id/index.php/KesehatanMasyarakat

DOI: https://doi.org/10.51544/jkmlh.v6i2.2365

TABEL 3 Rekapitulasi Hasil Pengisian Kuisioner Aspek Pengetahuan

\begin{tabular}{lcc}
\hline Tingkat Pengetahuan & Responden & Persentase \\
\hline Rendah & 10 & $36 \%$ \\
\hline Sedang & 11 & $39 \%$ \\
\hline Tinggi & 7 & $25 \%$ \\
\hline
\end{tabular}

Berdasarkan TABEL 3 dapat diketahui bahwa sebagian besar responden memiliki tingkat pengetahuan sedang, yakni 39\% dari jumlah responden. Secara umum, responden telah memahami betul bahwa penggunaan rodentisida dapat mempengaruhi hewan non-target dan predator dari hewan pengerat itu sendiri. Meskipun jarang sekali ditemukan kucing liar yang mati setelah mengonsumsi hewan pengerat yang teracun, namun hal tersebut dapat berpengaruh terhadap ketahanan tubuh kucing liar. Lopez-Perea et al. (2017) menyatakan bahwa dalam banyak kasus, paparan AR pada predator tidak cukup untuk membunuh hewan, tetapi efek sub-mematikan dapat mengganggu kebugaran individu.
Masih belum banyak masyarakat yang mengetahui bahwa rodentisida nabati lebih aman digunakan dibandingkan rodentisida sintetis. Hal tersebut dikarenakan masyarakat tidak mengetahui adanya jenisjenis rodentisida. Masyarakat hanya mengetahui jenis rodentisida yang memang dijual di sekitar lingkungan pasar. Rodentisida nabati atau biasa disebut juga dengan biorodentisida lebih ramah lingkungan dibandingkan rodentisida sintesis. Menurut Pramestuti et al. (2018) penggunaan biorodentisida memiliki beberapa keuntungan diantaranya adalah biorodentisida jenis ini relatif aman, ramah lingkungan, murah, serta mudah diperoleh.

\section{Aspek Sikap}

Hasil pengisian kuisioner aspek sikap mengenai penggunaan rodentisida dan penanganan residu rodentisida dapat dilihat pada TABEL 4 berikut ini.

TABEL 4 Rekapitulasi Hasil Pengisian Kuisioner Aspek Sikap

\begin{tabular}{lcc} 
Sikap & Responden & Persentase \\
\hline Tidak Baik & 0 & $0 \%$ \\
\hline Cukup Baik & 16 & $57 \%$ \\
\hline Baik & 12 & $43 \%$
\end{tabular}

Berdasarkan TABEL 4 di atas, dapat diketahui bahwa secara garis besar masyarakat Pasar Ngrandu memiliki sikap cukup baik dalam hal penggunaan rodentisida dan penanganan residu rodentisida dengan rata-rata nilai sikap 68.Sebanyak $61 \%$ responden menyetujui bahwa penggunaan rodentisida sesuai anjuran dan petunjuk penggunaannya.
Sebagian besar responden berpendapat bahwa penggunaan rodentisida yang sesuai dosis lebih efektif dibandingkan jika tidak sesuai dosis. Namun, masih ada beberapa responden yang menggunakan rodentisida dengan takaran yang diperikirakan cukup menurut responden tersebut.

Sebesar 46,4\% responden menggunakan sarung tangan ketika bersentuhan dengan 
ISSN: 2528-4002 (Media Online)

ISSN: 2355-892x (Print)

Online: http://e-journal.sari-mutiara.ac.id/index.php/KesehatanMasyarakat

DOI: https://doi.org/10.51544/jkmlh.v6i2.2365

rodentisida. Namun, sebagian besar lagi yakni $53,5 \%$ responden enggan menggunakan sarung tangan dengan alasan bahwa mereka harus mengeluarkan uang untuk membeli sarung tangan. Masyarakat lebih memilih untuk mencuci tangan dengan sabun setelah bersentuhan langsung dengan rodentisida. Hal tersebut cukup berbahaya ketika para pengguna lupa dan memakan makanan tanpa mencuci tangan dengan air dan sabun terlebih dahulu.Rodentisida dibuat untuk membunuh hewan pengerat.Potensi racun pada rodentisida dapat membunuh tikus, jika dikonsumsi oleh manusia makaakan memiliki efek yang serupa. Kalaupun tidak mematikan, rodentisida tersebut berpotensi memanifestasikan toksisitasnya pada berbagai organ vital tubuh (Abilash \& Jayakaran).

Sebesar $71,4 \%$ responden telah meletakkan rodentisida di tempat yang jauh dari kucing liar. Namun, masih terdapat beberapa responden yang meletakkan di tempat yang sering didatangi kucing liar. Mayoritas masyarakat pasar membuang bangkai tikus teracun ke dalam pusat pembuangan sampah Pasar Ngrandu. Tempat pembuangan tersebut sering didatangi kucing liar karena banyak sampah dari ikan-ikan yang sudah tidak segar dibuang di tempat tersebut.Menghindari penempatan rodentisida di daerah yang kemungkinan akan dikunjungi oleh satwa liar merupakan profesional manajemen

\section{KESIMPULAN}

Berdasarkan paparan hasil penelitian dan pembahasan di atas, dapat disimpulkan sebagai berikut. hama yang dapat mengurangi risiko paparan nontarget, termasuk keracunan sekunder predator, dengan tetap memberikan pengendalian hama komensal yang efektif (Burke et. al., 2021).

Agar bangkai tikus teracun tidak terjangkau oleh kucing liar, bangkai tersebut sebaiknya dikubur dalam tanah atau dapat juga dilakukan dengan mengatur sistem pengelolaan sampah pasar.Namun, 71,4\% Masyarakat Pasar Ngrandu tidak menyetujui hal tersebut dikarenakan tidak adanya lahan untuk mengubur sampah organik. Menurut Sahil (2016) dalam Zuchriyastono \& Purnomo (2020) ada beberapafaktor yang menjadi pengaruh dalam pengolahan sampah yang dianggap sebagai penghambat antara lain adalah penyebaran dan kepadatan penduduk, sosial-ekonomi, dan karakteristik lingkungan fisik, sikap dan perilaku, serta budaya masyarakat.Sebesar $71,4 \%$ responden juga tidak menyetujui bahwa mereka akan membawa kucing liar ke dokter hewan apabila ditemukan kucing liar yang teracun. Menurut salah seorang pengguna rodentisida, kucing-kucing liar yang ada di pasar merupakan kucing buangan yang tidak diinginkan oleh majikannya. Hal ini yang kemudian membuat masyarakat pasar juga kurang peduli ketika ada kucing liar yang teracun. Padahal kucing liar merupakan salah satu biodiversitas yang perlu dilestarikan sebagai warisan kepada para penerus.

1. Sebagian besar responden memiliki tingkat pengetahuan sedang, yakni 39\% dari jumlah responden. Secara umum, responden telah memahami betul bahwa 
ISSN: 2528-4002 (Media Online)

ISSN: 2355-892x (Print)

Online: http://e-journal.sari-mutiara.ac.id/index.php/KesehatanMasyarakat

DOI: https://doi.org/10.51544/jkmlh.v6i2.2365

penggunaan rodentisida dapat

mempengaruhi hewan non-target dan predator dari hewan pengerat itu sendiri. Meskipun jarang sekali ditemukan kucing liar yang mati setelah mengonsumsi hewan pengerat yang teracun, namun hal tersebut dapat berpengaruh terhadap ketahanan tubuh kucing liar.

2. Masyarakat Pasar Ngrandu memiliki sikap cukup baik dalam hal penggunaan rodentisida dan penanganan residu rodentisida dengan rata-rata nilai sikap DAFTAR PUSTAKA

Abhilash, K. P., \& Jayakaran, J. J. (2019).

Rodenticide poisoning: Literature review and management. Current Medical Issues, 17(4), 129. https://doi.org/10.4103/cmi.cmi_54_19

Burke, C. B., Quinn, N. M., \& Stapp, P. (2020). Use of Rodenticide Bait Stations by Commensal Rodents in Southern California. UC Agriculture \& Natural Resources Proceedings of the Vertebrate Pest Conference, 1-3.

I Mahmood, S R Imadi , K Shazadi , A Gul, and K. R. H. (2016). Effects of Pesticides on Environment. Plant, Soil and Microbes: Volume 1: Implications in Crop Science, 1, 253-269. https://doi.org/10.1007/978-3-31927455-3

López-Perea, J. J., \& Mateo, R. (2018). Secondary Exposure to Anticoagulant Rodenticides and Effects on Predators. https://doi.org/10.1007/978-3-31964377-9_7
68. Namun, masyarakat pasar juga kurang peduli ketika ada kucing liar yang teracun dengan beberapa alasan yang cukup masuk akal.

3. Beberapa saran yang dapat disampaikan berdasarkan pembahasan di atas, antara lain: penyuluhan mengenai penggunaan rodentisida untuk meminimalisir dampak, penyuluhan mengenai pentingnya melestarikan biodiversitas dan pengadaan lembaga penangkaran kucing liar yang dibuang.

Pramestuti, N., Sianturi, C. L. J., Ikawati, B., \& Anggara, A. (2018). Rodentisida nabati papain papaya (Carica papaya L.) sebagai alternatif pengendali mencit. Vektora, 10(2), 83-88.

Quinn, N. (2019). Assessing individual and population-level effects of anticoagulant rodenticides on wildlife. Human-Wildlife Interactions, 13(2), 200-211. https://doi.org/10.26077/y9tjew86

Zuchriyastono, M. A., \& Purnomo, E. P. (2020). ANALISIS LINGKUNGAN LAHAN TEMPAT PEMBUANGAN SAMPAH TERPADU TERHADAP KESEHATAN MASYARAKAT SEKITAR Studi Kasus: Tempat Pembuangan Sampah Terpadu Piyungan (TPST). Jurnal Kesehatan Masyarakat Dan Lingkungan Hidup, 5(1), 22-28. http://e-journal.sarimutiara.ac.id/index.php/Kesehatan_Ma syarakat/article/view/641/575 